\title{
The Effect of Realistic Mathematics Approach and Self-Efficacy on Students' Mathematical Problem Solving Ability in Fifth Grade Student of Gracia Sustain Private Elementary School Medan
}

\author{
Anita Rebekawati \\ Department of Basic Education \\ State University of Medan \\ Medan, Indonesia \\ anita.rebekawati@yahoo.com
}

\author{
Waminton Rajagukguk \\ Faculty of Mathematics and Natural Science \\ State University of Medan \\ Medan, Indonesia
}

\author{
Zulkifli Matondang \\ Faculty of Engineering \\ State University of Medan \\ Medan, Indonesia
}

\begin{abstract}
This study aims to determine: (1) the effect of realistic mathematics approach on student mathematics problemsolving ability; (2) the effect of self-efficacy on student mathematics problem-solving ability; (3) the interaction between realistic mathematics approach and self-efficacy on student mathematics problem-solving ability. This research is a quasiexperimental research. The population research is students of class V-A, V-B, and V-C Gracia Sustain Private Elementary School. The sample in this research is class $\mathrm{V}$-A as the control class that consists of 30 students which were taught using the conventional approach and for class V-B for the experimental class which was taught using realistic mathematics approach. The instruments used were: (1) mathematics problem-solving test, that was essay test; (2) self-efficacy questionnaire sheet. These instruments had fulfilled the terms of validity and reliability coefficient. The findings of the research showed that: (1) there are effects of realistic mathematics approach towards student mathematics problem-solving ability. It is shown by the mathematics problem-solving outcomes of students who received the realistic mathematics approach got mean score as 78,37 while the mathematics problem-solving outcomes of student who received the conventional approach got mean score as 67,70; (2) based on the results of data calculations can be seen that the mathematics problem-solving ability on students who have high self-efficacy got mean score as 79,38 while the mathematics problem-solving ability on students who have low self-efficacy got the mean score as 64,18; and (3) the hypothesis result testing showed that there is no interaction between the use of realistic mathematics approach and self-efficacy towards students mathematics problem-solving ability.
\end{abstract}

Keywords- Realistic mathematics approach, conventional approach, mathematics problem-solving ability, and self-efficacy.

\section{INTRODUCTION}

Mathematics has a very important role in various aspects of human life. In education, mathematics is often used as a parameter of intelligence and student success in pursuing an education level. Moreover, mathematics is seen as an important provision in the worldwide. The fact is that the rapid growth in science and technology which is happening in the entire world cannot be separated from the mathematics contributions. Without mathematics, it's not possible for science and technology achieved rapid development where its benefits have been received nowadays by the entire world. In fact, Santoso [1] states that the progress of developed countries, until now becoming dominant, turns out $60 \%$ - $80 \%$ depends on their success in mathematics.

Basically, mathematics learning itself has a function as a means to develop the ability to think logically, analytically, systematically, critically, critically and collaboratively. More specifically, as stated by the National Council of Teachers of Mathematics (NCTM, 2000) that mathematics aims to form mathematical communication abilities, mathematical reasoning abilities, mathematical problem solving abilities (mathematical problem solving)), the ability of mathematical connections (mathematical connections), and the ability of mathematical representation (mathematical representation).

This is in line with the National Council of Teachers of Mathematics (NCTM, 1980) which states that "problemsolving must be the focus of the curriculum" and the National Council of Supervisors of Mathematics (NCSM, 1977) which confirms that "learning to solve problems is the principal reason for studying mathematics ".

Armed with the ability to solve problems obtained through learning mathematics, students are expected to be able to solve problems both problems in mathematics, problems in other sciences, and problems faced in everyday [2]. But in reality, it was found that mathematics education in Indonesia had not yet reached the expected goals. This can be seen from the mathematics achievement index of Indonesian students which is still classified as very low when compared to the achievements of students from other countries. Here are some facts that show the low mathematical achievements of Indonesian students. In PISA 2015, Indonesia's science score 
was 403, mathematics 386, and reading 397 [3]. Science ranks 62, math 63 and read 64, from a total of 70 countries surveyed by PISA. This means that Indonesia is always in the bottom 10 . Especially if you look in the PISA achievement in 2012, the ranking of science, mathematics, and reading in Indonesia are $64,65,61$ of 65 countries with a science score of 382, math 375 , and reading 396. From the results of the 2015 PISA test and evaluation, the performance of students in Indonesia is still relatively low. Indonesia's ranking and the average score do not differ greatly from the results of previous PISA tests and surveys in 2012 which were also in the low mastery of material group. This condition is also relevant to the results of the 2015 TIMSS where for the first time Indonesia took part in a fouryear survey to assess the mathematical and scientific ability of fourth grade elementary school students. But again, Indonesia is at the bottom. A math score of 397, put Indonesia at number 45 out of 50 other countries. In the field of science, with a score of 397, Indonesia ranks 45 th out of 48 countries. From the above explanation, it is clear that the achievements of Indonesian students, especially in the field of mathematics still tend to be low when compared to other countries. The survey results above indicate the failure of mathematics learning in Indonesia [4].

From this description, it is clear that there is a need for renewal in mathematics education in Indonesia so that mathematics education becomes a forum that can truly maximize the potential of students 'mathematical problemsolving abilities given that the real focus of mathematics learning is to hone students' problem-solving abilities. The phenomenon of the low ability to solve mathematical problems also occurs in one of the elementary schools in the province of North Sumatra, precisely at Gracia Sustain Private Elementary School (SDS Gracia Sustain) in the city of Medan [5].

Based on facts in the field obtained from the observations and interviews of researchers with students and mathematics teachers at Gracia Sustain Elementary School, it can be concluded that in general the ability of Gracia Sustain Elementary School students in solving mathematical problem solving tends to be low. Most students expressed that they have difficulty and tend not to like math problems, especially those related to story problems (problem-solving problems).

From the results of observations and interviews, researchers found that the process of learning mathematics that takes place in the field has not been able to create a learning atmosphere that allows the formation of mathematical problem-solving abilities.

Students are also only accustomed to working on routine problems in math textbooks. In addition, the mathematics learning process that has taken place so far is learning that only emphasizes memorization of mathematical formulas, mathematical problem solving is only focused on the solution offered by the teacher, students tend to be passive and not creative because the communication that occurs during the mathematics learning process tends to be more one-way communication from teacher to student. It is suspected that the causes of the things above are motivated by the learning approach applied at Gracia Sustain Elementary School in mathematics still using conventional learning [6].
In addition to the cognitive aspects of students, students' affective aspects are also necessary attention because both have a very close relationship. Students are sometimes unsure of their decision to solve various mathematical problems [7]. One part of students' beliefs is their self-belief in mathematics. Often students are not able to show academic achievement optimally in accordance with their abilities. One reason is that they feel unsure that they will be able to complete the tasks assigned to them. For students, this kind of belief is very necessary because it will make students enthusiastic and feel capable of themselves. This confidence is called self-efficacy.

For this reason, a renewal of the learning approach is needed. One approach to learning mathematics that suits the needs of elementary students is the realistic mathematics approach. Basically, a realistic mathematics approach utilizes reality in the process of learning mathematics. What is meant by reality here is not only related to the real world but also relates to something students can imagine. So the realistic mathematical approach in the learning process starts with 'real' problems in the context of the real world, as well as in the mind (can be imagined) [8]. The realistic mathematics approach begins with raising real problems related to students' daily lives and it is hoped that the real problems will be used as sources for the emergence of mathematical concepts obtained by students through their learning experiences. Furthermore, by applying these mathematical concepts, students can solve mathematical problems. That means students find their own mathematical concepts through mathematical problem-solving activities [9].

\section{I.1 The Objectives of the Study}

The specific objectives of the this study were as follows :

1. To determine the effect of realistic mathematics approach on students' mathematical problem solving ability?

2. To determine the effect of self-efficacy on students' mathematical problem solving ability?

3. To determine the interaction between learning approach and self-efficacy on students' mathematical problem solving ability?

\subsection{Research Questions}

The study set out to address the following research questions:

1. Is there any effect of realistic mathematics approach on students' mathematical problem solving ability?

2. Is there any effect of self-efficacy on students' mathematical problem solving ability?

3. Is there any interaction between learning approach and self-efficacy on students' mathematical problem solving ability? 


\subsection{Null Hypotheses of the Study}

The following null hypotheses were tested:

1. $\mathrm{H}_{01}$ : There is no any effect of realistic mathematics approach on students' mathematical problem solving ability.

2. $\mathrm{H}_{02}$ : There is no any effect of self-efficacy on students' mathematical problem solving ability.

3. $\mathrm{H}_{03}$ : There is no interaction between learning approach and self-efficacy on students' mathematical problem solving ability.

\section{RESEARCH METHOD}

This research was conducted in Gracia Sustain elementary school Medan. The population in this study was the three classes of the fifth grade student of Gracia Sustain Medan in 2018-2019 academic year. They were V-A, V-B and V-C. The technique to take samples in this study was by using cluster random sampling.

This research used experimental method with quasi design of $2 \times 2$ factorial experiment design. Through this design, the effect of realistic mathematics approach and self-efficacy were compared towards the students' mathematical problem solving ability [10]. This research involved two sample classes which were given different treatments. In the experimental class, the treatment was given a realistic mathematical approach while in the control class the conventional approach was treated. The design of this study used pre-test and a post-test control group.

To look more deeply at the effect of learning through a realistic mathematics approach and self-efficacy on students' mathematical problem solving abilities, then at the end of this study the researchers conducted a final test (post-test) to measure students' mathematical problem solving abilities after being given the learning treatment using a realistic mathematics approach in the experimental and conventional approaches in the control class [11-13].

The relationship between the independent, dependent and moderator variables is presented in the research design as follows

Information :

$\mu \mathrm{A}_{1} \mathrm{~B}_{1}$ : Mean score of mathematical problem-solving ability on students were taught by using a realistic mathematical approach with high self-efficacy

$\mu A_{1} B_{2}$ : Mean score of mathematical problem-solving ability on students were taught by using a realistic mathematical approach with low self-efficacy

$\mu \mathrm{A}_{2} \mathrm{~B}_{1}$ : Mean score of mathematical problem-solving ability on students were taught by using conventional approaches with high self-efficacy

$\mu \mathrm{A}_{2} \mathrm{~B}_{2}$ : Mean score of mathematical problem-solving ability on students were taught by using conventional approaches with low self-efficacy

\section{RESULTS}

Tests of Between-Subjects Effects

Dependent Variable: Post-tes_KPM

\begin{tabular}{|c|c|c|c|c|c|}
\hline Source & $\begin{array}{l}\text { Type III } \\
\text { Sum of } \\
\text { Squares }\end{array}$ & df & $\begin{array}{l}\text { Mean } \\
\text { Square }\end{array}$ & $F$ & Sig. \\
\hline $\begin{array}{l}\text { Corrected } \\
\text { Model }\end{array}$ & $5066.305^{a}$ & 3 & 1688.768 & 11.395 & .000 \\
\hline Intercept & 289592.252 & 1 & 289592.252 & 1953.963 & .000 \\
\hline $\begin{array}{l}\text { Learning } \\
\text { approach }\end{array}$ & 725.623 & 1 & 725.623 & 4.896 & .031 \\
\hline Self_efficacy & 3275.585 & 1 & 3275.585 & 22.101 & .000 \\
\hline $\begin{array}{l}\text { Learning } \\
\text { approach * }\end{array}$ & 153.585 & 1 & 153.585 & 1.036 & .313 \\
\hline $\begin{array}{c}\text { Self_efficacy } \\
\text { Error }\end{array}$ & 8299.629 & 56 & 148.208 & & \\
\hline Total & 333398.000 & 60 & & & \\
\hline $\begin{array}{c}\text { Corrected } \\
\text { Total }\end{array}$ & 13365.933 & 59 & & & \\
\hline
\end{tabular}

a. R Squared $=.379$ (Adjusted R Squared $=.346)$

1. First Hypothesis

Ho: $\mu \mathrm{A} 1 \leq \mu \mathrm{A} 2$ : There is no effect of realistic mathematical approaches on students' mathematical problem-solving ability.

Ha: $\mu \mathrm{A} 1>\mu \mathrm{A} 2$ : There is an effect of a realistic mathematical approach on students' mathematical problem-solving ability.

Based on the ANOVA results in table above, it can be seen that students who were taught by using the realistic mathematics approach obtain mathematical problem-solving ability mean score of 75,275 while students who were taught using the conventional approach obtain mathematical problem-solving ability of 68,098 .

ANOVA test results for both learning approaches show the price of $\mathrm{f}_{\text {count }}$ is $4.896\left(\mathrm{~F}_{\text {table }}=4.01, \alpha=0.05\right), \mathrm{F}_{\text {count }}(4.896)>$ $\mathrm{F}_{\text {table }}(4.01)$ with a significance of $0.031<0.05$. Then it can be

\begin{tabular}{|c|c|c|c|}
\hline \multicolumn{2}{|c|}{ Ability } & \multicolumn{2}{|c|}{$\begin{array}{c}\text { Mathematical Problem- } \\
\text { Solving (A) }\end{array}$} \\
\hline \multicolumn{2}{|c|}{ Learning Approach } & $\begin{array}{c}\text { Realistic } \\
\left(\mathbf{A}_{1}\right)\end{array}$ & $\begin{array}{c}\text { Convensional } \\
\left(\mathbf{A}_{2}\right)\end{array}$ \\
\hline \multirow{2}{*}{$\begin{array}{c}\text { Self-efficacy } \\
\text { (B) }\end{array}$} & High $\left(\mathbf{B}_{1}\right)$ & $\mu A_{1} B_{1}$ & $\mu A_{2} B_{1}$ \\
\hline & LOw $\left(\mathbf{B}_{2}\right)$ & $\mu A_{1} B_{2}$ & $\mu A_{2} B_{2}$ \\
\hline
\end{tabular}

concluded that the results of hypothesis testing reject $\mathrm{H}_{0}$ or accept $\mathrm{H}_{\mathrm{a}}$ in the alpha level of 5\%. This shows that there is an influence of realistic mathematics approach to students' mathematical problem-solving abilities. From the result it can be concluded that realistic mathematics approach gave better influence on students' mathematical problem-solving ability rather than the students who were taught using conventional approach. 
2. Second Hypothesis

Ho: $\mu \mathrm{B} 1 \leq \mu \mathrm{B} 2$ : There is no effect on students' self-efficacy on students' mathematical problem-solving ability.

Ha: $\mu \mathrm{B} 1>\mu \mathrm{B} 2$ : There is an effect of students 'self-efficacy on students' mathematical problem-solving ability.

Based on the ANOVA results in table above, it can be seen that students who have high self-efficacy obtain mathematical problem-solving ability mean score of 79.311 while students who have low self-efficacy obtain mathematical problemsolving ability mean score of 64,063 .

ANOVA test results for both categories of self-efficacy show the price of $f_{\text {count }}$ is $22.101\left(\mathrm{~F}_{\text {table }}=4.01, \alpha=0.05\right), \mathrm{F}_{\text {count }}$ (22.101) $>\mathrm{F}_{\text {table }}(4.01)$ with a significance of $0.000<0.05$. Then it can be concluded that the results of hypothesis testing reject $\mathrm{H}_{0}$ or accept $\mathrm{Ha}$ in the alpha level of 5\%. This shows that there is an effect of self-efficacy on students' mathematical problem solving abilities. From the result it can be concluded that student with high self-efficacy gives a better influence on students' mathematical problems solving ability rather than student with low self-efficacy.

3. Third Hypothesis

Ho: $\mathrm{A}\rangle\langle\mathrm{B}=0$ : There is no interaction between learning approaches and self-efficacy on students' mathematical problem solving ability.

Ha: $\mathrm{A}><\mathrm{B} \neq 0$ : There is an interaction between learning approaches and self-efficacy towards students' mathematical problem-solving ability.

Based on the ANOVA results in table above, $f_{\text {count }}$ of $1.036($ Ftable $=4.01, \alpha=0.05)$ was obtained, $F_{\text {count }}(1.036)$ $\left\langle\mathrm{F}_{\text {table }}(4.01)\right.$ with a significance of $0.313>0.05$. Then it can be concluded that the results of the hypothesis test accept Ho, or reject $\mathrm{Ha}$ in the alpha level of 5\%. This shows that there is no interaction between the learning approach and self-efficacy on students' mathematical problem-solving ability. It means that there is no mutual influence between the learning approach and students' self-efficacy on students' mathematical problem solving abilities. This means that the difference in the average score of students' mathematical problem solving abilities with the category of high and low self-efficacy categories between students who are taught with a realistic mathematical approach and conventional approaches is not significantly different. So the difference in students 'mathematical problem-solving ability is due to the influence of the learning approach, not because of students' selfefficacy.

\section{CONCLUSIONS}

1. There is a significant influence of realistic mathematics approach to the mathematical problem solving ability on the fifth-grade students of SDS Gracia Sustain Medan.

2. There is a significant effect of self-efficacy on the mathematical problem-solving ability on fifth-grade students of SDS Gracia Sustain Medan.

3. There is no interaction between the learning approach and students' self-efficacy in influencing students' mathematical problem-solving abilities.

\section{REFERENCES}

[1] Hudojo, H (2005). Pengembangan Kurikulum dan Pembelajaran Matematika. Malang: UM Press.

[2] Soedjadi, R. (1994). Memantapkan Matematika Sekolah sebagai Wahana Pendidikan dan Pembudayaan Penalaran. Surabaya: Media Pendidikan Matematika Nasional.

[3] Alwisol. 2014. Psikologi Kepribadian. Malang: UMM Press.

[4] Bandura, A. 1998. Self-efficacy: Toward a Unifying Theory of Behavioral Change. Stanford University.

[5] Baron, R.A. dan Byrne, D. 2003. Psikologi Sosial. Airlangga: Jakarta.

[6] Fattah, H.A.H. 2017. Kepuasan Kerja dan Kinerja Pegawai -Budaya Organisasi, Perilaku Pemimpin, dan Efikasi Diri. Yogyakarta : Elmatera.

[7] Ormrod, J. E. 2008. Psikologi Pendidikan. Jakarta : Erlangga

[8] Musyaddad, K. 2013. Problematika Pendidikan di Indonesia. Edu-Bio; Vol.4, Tahun 2013.

[9] National Council of Supervisors of Mathematics (NCSM) (1977)

[10] National Council of Teacher of Mathematics (NCTM) (1980)

[11] National Council of Teacher of Mathematics (NCTM) (2000)

[12] Polya, G. 1973. How to Solve it. A New Aspect of Mathematical Method. Princetion: Princeton University Press.

[13] Ruseffendi, E.T. 2006. Pengantar Kepada Membantu Guru Mengembangkan Kompetensinya dalam Pengajaran Matematika untuk Meningkatkan CBSA. Bandung: Tarsito 